\title{
HUBUNGAN ANTARA TINGKAT KONSERVATISME PIHAK PENGAKUSISI DAN TINGKAT RETURN KEGIATAN MERGER- AKUISISI DARI PERSPEKTIF PIHAK PENGAKUISISI
}

\author{
Leona Ami \\ Fakultas Bisnis dan Ekonomika \\ Universitas Surabaya \\ amileona@gmail.com \\ Yie Ke Feliana \\ Fakultas Bisnis dan Ekonomika \\ Universitas Surabaya \\ yiekefeliana@staff.ubaya.ac.id
}

\begin{abstract}
This research investigate if timely loss recognitionis associated with return of merger - acquisition. In order to measure conservatism, we used Basu (1997) and Francis and Martin (2010) in Demsetz and Lehn (1985) to measure return. Model I with AcqCAR +/30 days and Model II with AcqCAR +/- 365 days shows there is no significant relation between conservatism and return from merger and acquisition decision. In addition, we find that Basu (1997) is not significant for sample in Indonesia .Paired sample t-test shows there is no significant changes in return related merger and acquisition decision.
\end{abstract}

Keywords: 1: Acquisition, 2: Merger, 3: Conservatism, 4: return, 5: profitability.

\section{PENDAHULUAN}

Aktivitas merger maupun akuisisi telah berlangsung di Indonesia sejak tahun 1995 ketika UU No. 1 Tahun 1995 tentang Perseroan Terbatas diperkenalkan kepada masyrakat. Aksi atau tindakan merger mulai lazim dikenal oleh masyarakat yaitu pada tahun 1998 ketika terjadi krisis ekonomi yang melanda Indonesia.Pada saat itu, sangat banyak perusahaan terutama perbankan yang goyah sehingga untuk memperkuat pondasinya, beberapa bank kemudian melakukan merger dan akhirnya membentuk Bank Mandiri yang luas dikenal saat ini.

Adanya suatu upaya untuk melakukan merger-akuisisi ternyata tidak hanya terjadi di Indonesia.Djalil (2001) dan Kusmargiani (2006), menjelaskan bahwa hal ini juga terjadi pada Negara-negara industri maju misalnya di Amerika, Jerman maupun Jepang. Pada tahun 1998 misalnya, Travelers Group dan Citicorp mengumumkan 
terjadinya merger dan membentuk Citi Group. Selanjutnya pada tahun 1999 Deutsche Bank di Jerman melakukan merger dengan Banker Trust yang berasal dari Amerika.

Lee dan Lee (2006), berpendapat bahwa merger dan akuisisi adalah dua hal yang berbeda. Akuisisi adalah aktivitas mengambil alih control perusahaan dengan membeli lebih dari 50\% kepemilikan atas perusahaan lain sedangkan merger adalah salah satu aktivitas kombinasi bisnis untuk membentuk satu bentuk baru yang berbeda dibandingkan sebelumnya.

Ketika sebuah perusahaan melakukan aktivitas merger maupun akusisi, perusahaan pasti memiliki tujuan tertentu yang ingin dicapai. Rezaee (2001), secara singkat menjelaskan bahwa tujuan utama dilakukannya merger dan akusisi adalah terkait dengan masalah efektivitas dan efisiensi kegiatan operasional. Namun motif atau tujuan utama dibalik semua kegiatan atau aktivitas merger dan akuisisi yaitu memaksimalkan kekayaan pemegang saham.

Wang (2009) mendefiniskan konservatisme dipandang sebagai prinsip dimana akuntan melaksanakan suatu praktik kehatian - hatian yang memadai dalam mengakui suatu transaksi yang berakibat pada ketidakpastian secara ekonomi. Konsep akuntansi secara modern memandang prinsip konservatisme sebagai suatu prinsip yang tidak mencakup atau mengijinkan adanya salah saji atau manipulasi dalam suatu akun baik dengan melakukan understating maupun overstating dalam suatu periode, jika tidak ada ketidakpastian secara ekonomi.

Peningkatan kekayaan pemegang saham akibat adanya proses merger dan akuisisi dapat tercipta melalui keuntungan akibat transaksi maupun adanya transfer asset dari entitas yang di merger maupun di akusisi.Ketika perusahaan melakukan merger dan akuisisi, ada dua kemungkinan yang dihadapi yaitu mengalami kerugian atau mendapatkan keuntungan. Jika perusahaan menerapakan prinsip konservatisme, maka ketika terdapat indikasi bahwa perusahaan akan mengalami kerugian maka ia akan segera mengakui kerugian itu di awal. Namun sebaliknya, jika perusahaan tidak menerapkan prinsip konservatisme pada perusahaan, maka ketika belum ada 
kepastian mengenai kondisi perusahaan apakah mengalami kerugian atau tidak, maka manajer tidak akan mengakui adanya kerugian di awal melainkan di masa yang akan datang.

\section{KAJIAN PUSTAKA DANPENGEMBANGAN HIPOTESIS}

Sebuah perusahaan melakukan aktivitas merger dan akuisisi adalah dengan tujuan untuk mendapatkan laba maupun adanya transfer kekayaan dari perusahaan target kepada perusahaan miliknya. Ketika melakukan aktivitas merger maupun akusisi ada dua kemungkinan yang dihadapi oleh perusahaan yaitu keuntungan maupun kerugian.

Jika sebuah perusahaan menerapkan prinsip konservatisme, maka ia akan cenderung mengakui adanya kerugian di awal dan mengakui adanya keuntungan ketika sudah ada kepastian bahwa keuntungan tersebut benar - benar akan diperoleh. Hal ini didasarkan dari pemikiran bahwa ketika perusahaan sudah mengakui semua kerugian di awal, diharapkan setelah mengalami kerugian yang bersifat temporer ini perusahaan akan memperbaiki keuangannya. Jika semua kerugian sudah diumumkan pada kuartal pertama, maka pada akhir periode setelah semua keuntungan atau pendapatan diakui, maka grafik kinerja perussahaan akan mengalami peningkatan. Sehingga jika dilihat berdasarkan grafik yang ada, maka perusahaan cenderung memperoleh keuntungan.

Basu (1997) menjelaskan bahwa konservatisme menyebabkan laba menggambarkan atau merefleksikan berita buruk lebih cepat dibandingkan dengan berita baik.Ia menjelaskan bahwa konservatisme menggambarkan kecendrungan akuntan dalam memverifikasi potensi keuntungan secara lebih hati - hati dibandingkan dengan potensi kerugian. Basu menemukan bahwa jika perusahaan menerapkan prinsip konservatisme maka mereka akan lebih tepat waktu dalam mengakui terjadinya kerugian arus kas dibandingkan mengakui adanya potensi keuntungan dalam arus kas. Hal ini mengindikasikan bahwa dengan adanya 
konservatisme maka ketika melakukan suatu aktivitas, fokusnya akan berusaha menghindari aktivitas yang berpotensi menimbulkan kerugian arus kas.

Kravet (2014) melakukan penelitian untuk menguji apakah konservatisme berhubungan dengan tindakan manajer dalam mengambil keputusan investasi. Penelitian ini membuktikan bahwa jika manajer semakin bersikap semakin konservatif, maka ia cenderung melakukan akusisi yang memiliki risiko lebih rendah. Hal ini konsisten dengan teori dimana perusahaan yang bersikap konservatif cenderung menghindari risiko untuk menghindari terjadinya kerugian dalam jumlah besar yang akhirnya berdampak pada dilakukannya hutang.

Francis dan Martin (2010) melakukan penelitian mengenai hubungan antara pengakuan kerugian secara tepat waktu dengan pengambilan keputusan investasi.Keduanya menemukan bahwa perusahaan yang menerapkan konservatisme semakin tinggi menghasilkan laba akuisisi yang lebih tinggi.Hal ini disebabkan karena pengakuan kerugian pada lebih awal dapat membuat kinerja perusahaan pada akhir periode terlihat lebih baik karena terjadi perbaikan atas kerugian yang sebelumnya dialami.Akhirnya, hal ini berdampak pada nilai perusahaan.

Jika perusahaan tidak menerapakan prinsip konservatisme, maka tidak ada yang mengontrol tindakan manajemen dalam melakukan pengambilan keputusan. Manajemen akan cenderung ceroboh dalam pengambilan keputusan karena ia akan berusaha mencari cara untuk memaksimalkan nilai perushaan untuk mendapatkan bonus yang lebih tinggi. Hal ini juga cenderung mengarahkan tindakan manajer pada kegiatan atau aktivitas yang negatif yaitu dengan melakukan manipulasi laba ketika investasi atau akuisisi yang dilakukan menghasilkan nilai negatif. Dalam penelitian ini peneliti berusaha membuktikan bahwa dengan adanya konservatisme yang diterapkan oleh pengakuisisi maka ada kemungkinan lebih tinggi bagi perusahaan pengakusisi untuk mendapatkan abnormal return.

$\mathrm{H} 1$ = Terdapat hubungan yang positif antara tingkat konservatisme pihak pengakuisisi dengan tingkat return perusahaan pengakuisisi. 


\section{METODE PENELITIAN}

Obyek penelitian ini menggunakan data sekunder yang diperoleh dari website BEI. Perusahaan yang dipilih adalah perusahaan yang memiliki data lengkap terkait laporan tahunan serta harga sahamnya.Periode penelitian yaitu perusahaan yang melakukan merger dan akuisisi sejak tahun 2010-2015. Penelitian dimulai sejak tahun 2010 dimana hal ini berkaitan dengan adanya penerapan PP No 57 Tahun 2010 dan diakhiri pada tahun 2015 dimana data pada tahun 2015 merupakan data terakhir atau terbaru yang tersedia. Dalam penelitian ini, peneliti melihat dari perpektif pihak pengakuisisi dan bukan sebaliknya karena adanya keterbatasan data.Keterbatasan data disebabkan karena pihak yang diakuisisi belum tentu merupakan perusahaan yang sudah listing sehingga ketersediaan datanya juga sangat minim. Hal ini juga menjadi bahan pertimbangan bagi peneliti dalam memilih variabel dimana peneliti tidak mengikutsertakan variabel dari pihak yang diakuisisi karena sebagian besar datanya tidak tersedia, misalnya : harga akuisisi.

Model yang digunakan untuk penelitian adalah model yang digunakan untuk membuktikan hipotesis 1, peneliti menggunakan model pengukuran oleh Basu (1997). Penulis menggunakan model Basu karena dalam mengukur penerapan konservatisme, model ini adalah model yang paling umum digunakan. Obyek penelitian yang digunakan oleh peneliti adalah perusahaan yang sudah go public sehingga model yang paling cocok digunakan adalah model pendekatan berdasarkan pasar seperti yang digunakan oleh Basu. Model penelitian ini adalah model penelitian modifikasi yang dilakukan oleh Francis dan Martin (2010) .Model tersebut kemudian disesuaikan oleh penulis dengan kondisi ketersediaan data di Indonesia.

Selanjutnya, penulis melakukan modifikasi dengan membagi model yang dibuat oleh Francis dan Martin (2010) kedalam dua bentuk yaitu event studies dengan AcqCAR +/- 30 Hari dan accounting studies dengan +/- AcqCAR 365 Hari. Menurut Grigorieva dan Petrunina (2013) Event studies berusaha mempelajari reaksi pasar atas 
pengumuman aktivitas merger dan akuisisi sedangkan accounting studies berusaha melihat perubahan pada laporan keuangan sebelum dan sesudah aktivitas merger dan akuisisi dalam rangka memahami perubahan pada performance perusahaan.

Hipotesis yang akan dibuktikan adalah Terdapat hubungan yang positif antara profitabilitas yang diharapkan dari pihak peng-akuisisi dengan tingkat konservatisme pihak peng-akuisisi dengan menggunakan model berikut:

$$
\begin{aligned}
& x_{i t-1}=\quad \beta_{1}+\beta_{2} D_{i, t-1}+\beta_{3} R_{i, t-1}+\beta_{4} D_{i, t-1} * R_{i, t-1}+\beta_{5} A c q C A R_{i, t} \\
& +\beta_{6} A_{c q C A R_{i, t}} * D_{i, t-1}+\beta_{7} A c q C A R_{i, t} \geqslant R_{i, t-1}+\beta_{8} A_{c q} C A R_{i, t} \\
& * \boldsymbol{D}_{i, t-1} * \boldsymbol{R}_{i_{i}, t-1}+\beta_{g} \text { Leverage }_{i, t-1} * R_{\tilde{i}, t-1}+\beta_{10} \text { Leverage }_{i, t-1} \\
& \text { * } D_{i, t-1} * R_{i, t-1}+\beta_{11} \log (\text { assets })_{i, t-1} * R_{i, t-1} \\
& +\beta_{12} \log (\text { assets })_{i, t-1} \leqslant D_{i, t-1} * R_{i, t-1}+\beta_{13} M B_{i, t-1} * R_{i, t-1} \\
& +\beta_{14} M B_{i, t-1} * D_{i, t-1} * R_{i, t-1}+e_{i, t}
\end{aligned}
$$

$x_{i, t-1}$ merupakan variabel dependen dalam pene $\cdots . .(1)$ int-1 merupakan laba perusahaan dibagi dengan nilai pasar. Dengan kata lain $x_{t-1}$ dapat diartikan dengan net income dibagi dengan market value of equity pada tahun $\mathrm{t}-1$ yaitu tahun sebelum terjadinya akuisisi.Variabel Dummy pada penelitian akan dianggap bernilai sama dengan 0 (nol) jika Return $\geq 0$ (positif), dan bernilai sama dengan 1 jika Return $<0$ (negative). Return adalah selisih nilai pasar pada akhir tahun buku dibandingkan dengan nilai pasar pada awal tahun buku dibagi dengan nilai pasar pada awal tahun sebelum terjadi akuisisi. Ketiga variable ini merupakan variabel utama dalam pengukuran konservatisme menurut model Basu (1997).

CAR pihak pengakusisi dihitung dengan menggunakan cumulative abnormal return sesuai dengan AcqCAR +/- 30 Hari dan model IIAcqCAR +/- 365 Hari.Abnormal return pada penelitian ini adalah return company - return market ( di Indonesia menggunakan IHSG). Leverage diperoleh dari nilai buku dari hutang yang dibagi dengan nilai buku dari total asset pada t-1 (1 tahun sebelum terjadinya akuisisi). Firm size diperoleh dengan natural logarithm dari total assets pada tahun t1 yaitu tahun sebelum terjadinya akuisisi. Market to book adalah nilai pasar dari ekuitas yang diperoleh dari harga pasar perlembar saham dikali jumlah saham beredar 
dibagi dengan total ekuitas berdasarkan nilai buku yaitu harga saham pada akhir periode t-1 dikali dengan lembar jumlah saham beredar pada t-1 kemudian dibagi dengan total buku ekuitas pada tahun $\mathrm{t}-1$.

Hipotesis dalam penelitian ini dianggap terbukti berhubungan positif apabila $\beta_{8}>0$ yaituincremental timeliness digunakan untuk mengukur ketepatan pengakuan kerugian dan jumlah $\beta_{7}+\beta_{8}>0$ dan secara signifikan tidak sama dengan 0 apabila jumlah timeliness digunakan untuk mengukur ketepatan pengakuan kerugian.

\section{HASIL DAN PEMBAHASAN}

Berdasarkan hasil regresi pada model I dengan AcqCAR +/- 30 Hari ditemukan bahwa tidak terdapat hubungan yang signfikan antara kedua variable independen CARR dan CARDR dengan variabel $x_{t-1}$. Hal ini $x_{t-1}$ dilihat berdasarkan hasil uji t dengan signifikansi di atas 5\%. Hal ini membutkikan bahwa tidak terdapat hubungan antara tingkat konservatisme sebelum akuisisi yang menggunakan model Basu (1997) dengan return yang diperoleh pihak pengakuisisi setelah aktivitas merger dan akuisisi dilakukan sehingga hipotesis dalam model ini ditolak.

Hasil regresi pada model II ditemukan bahwa tidak terdapat hubungan yang signfikan antara kedua variable independen CARR dan CARDR dengan variabel $x_{t-1} \mathrm{Hal}$ ini bisa dilihat berdasarkan hasil uji t dengan signifikansi di atas $5 \%$. Hal ini membutkikan bahwa tidak terdapat hubungan antara tingkat konservatisme sebelum akuisisi yang menggunakan model Basu (1997) dengan return yang diperoleh pihak pengakuisisi setelah aktivitas merger dan akuisisi dilakukan sehingga hipotesis dalam model ini ditolak.

Peneliti kemudian melakukan pengujian tambahan untuk menemukan penyebab tidak signifikannya model regresi dalam penelitian ini. Selanjutnya, peneliti melakukan uji regresi dasar terhadap model Basu (1997) yaitu $x_{t-1}=\mathrm{R}, \mathrm{D}, \mathrm{DR}$ untuk 
melihat apakah variabel dasar dalam mengukur konservatisme di Indonesia signifikan.

Dalam model I maupun model II, model dasar yang digunakan dalam mengukur tingkat konservatisme tidak signfikan dengan kondisi yang ada di Indonesia. Hal ini terlihat dari signifikansi masing - masing variabel dasar independen yang digunakan dalam mengukur tingkat konservatisme yang memiliki tingkat signifikansi di atas 5\%. Hal ini menunjukkan bahwa karena model dasar yang digunakan untuk mengukur tingkat konservatisme tidak signifikan sehingga hubungan antara tingkat konservatisme dan tingkat return juga menjadi tidak signifikan.

Pengujian tambahan lainnya yang dilakukan oleh peneliti adalah uji beda rata-rata paired sample t-test terhadap variabel CARsebelum dan sesudah dengan menggunakan sampel yang sama. Dalam regresi 1 , peneliti melakukan uji beda rata rata dari CAR tepat pada 30 hari sebelum akuisisi dan 30 hari setelah akusisi. Tidak hanya itu, peneliti juga melakukan uji beda rata - rata pada CAR selama 30 hari sebelum akuisisi hingga tanggal akuisisi dan CAR selama 30 hari sejak tinggal tanggal akuisisi. Dalam regresi ke II, peneliti juga melakukan pengujian tambahan yaitu melakukan uji beda rata-rata paired sample t-test terhadap variabel CAR +/365 Hari sebelum dan sesudah dengan menggunakan sampel yang sama. Tidak hanya itu, peneliti juga melakukan uji beda rata - rata pada CAR selama 365 hari sebelum akuisisi hingga tanggal akuisisi dan CAR selama 365 hari sejak tinggal tanggal akuisisi.

Hasil uji beda rata- rata baik dalam model maupun model II menunjukkan hasil yang tidak signifikan. Hal ini menunjukkan bahwa tingkat return baik sebelum dan sesudah tanggal akuisisi tidak dipengaruhi oleh aktivitas merger dan akuisisi yang dilakukan oleh pihak pengakuisisi.

Dari hasil uji t pada model II, diketahui bahwa LeverageRD memiliki tingkat signifikansi dibawah 5\% yaitu 0.003. Hal ini dimungkinkan karena dengan dengan 
menurunnya return perusahaan (dalam hal ini menjadi negative) yang dikaitkan dengan tingkat leverage yang tinggi mengindikasikan bahwa sebuah perusahaan memiliki kinerja yang rendah sehingga prospek di masa yang akan datang kemungkinan mengalami penurunan yang akhirnya berdampak pada earnings perusahaan. Tidak hanya itu, semakin tinggi tingkat leverage yang dimiliki oleh perusahaan, maka jumlah interest yang harus dibayarkan juga akan semakin tinggi dimana hal ini akhirnya mempengaruhi earnings after interest and tax. Hal ini sejalan dengan penelitian yang dilakukan oleh Moradiet al. (2010), menemukan bahwa semakin rendah abnormal return suatu perusahaan, maka hal ini akan berdampak pada menurunnya tingkat kepercayaan yang diberikan oleh pihak investor. Jika capitral structure mengalami perubahan yang signifikan seperti perubahan pada leverage, maka hal ini akan semakin menimbulkan pertanyaan bagi investor mengenai kinerja perusahaan yang sesungguhnya dimana investor merasa bahwa earnings yang dilaporkan merupakan hasil dari manajemen laba.

Dari hasil uji t pada model II, Variabel LogAssetR dan LogAssetRD diketahui tidak memiliki hubungan dengan earnings. Jika returns mengalami peningkatan maupun penurunan yang dikaitkan dengan ukuran perusahaan tidak memiliki hubungan dengan earnings perusahaan. Hal ini sejalan dengan penelitian yang dilakukan oleh Niresh dan Velnampy (2014) yang menemukan bahwa tinggi rendahnya tingkat return dan ukuran perusahaan tidak mempengaruhi laba bersih perusahaan dimana hal ini dimungkinkan ketika perusahaan melakukan listing di bursa, akan terjadi perubahan kepemilikan yang juga dapat berdampak pada perubahan manajemen. Ketika terjadi perubahan kepemilikan, maka focus perusahaan juga dapat mengalami perubahan yaitu dari focus pada profit menjadi focus pada managerial utility. Hal ini sejalan dengan kondisi sample dalam penelitian ini yaitu semuanya merupakan perusahaan yang listing di bursa efek Indonesia.

Dari hasil uji t pada model II, Variabel lainnya yaitu MBR dan MBRD diketahui tidak memiliki hubungan dengan earnings. Jika returns mengalami peningkatan maupun penurunan yang dikaitkan dengan market to book pihak 
pengakusisi tidak memiliki hubungan yang signifikan dengan earnings. Hal ini sejalan dengan penelitian yang dilakukan oleh Senthilkumar (2009) dan Shafana et al. (2013) yang menyatakan bahwa ukuran marketto book tidak memiliki hubungan yang signifikan dengan earnings karena dalam mengambil keputusan operasioanal yang nantinya akan berdampak pada earnings yang diperoleh oleh perusahaan, manajemen tidak memasukkan market to book sebagai bahan pertimbangan.

\section{KESIMPULAN}

Baik dalam model I maupun model II menunjukkan bahwa hipotesis I ditolak. Hal ini dikarenakan model dasar yang digunakan dalam penelitian ini menunjukkan hasil yang tidak signifikan. Selain itu, hasil uji beda rata- rata menunjukkan bahwa baik sesudah maupun sebelum dilakukannya aktivitas merger dan akuisisi tidak terdapat perubahan yang signifikan pada tingkat return perusahaan.

Terdapat beberapa indikasi lainnya yang mungkin menyebabkan mengapa tidak terdapat hubungan antara tingkat konservatisme dengan tingkat return pihak pengakusisi salah satunya adalah baik dalam regresi I maupun regresi II, variabel earnings, Leverage, Log Asset dan market to book merupakan nilai dari prior year sedangkan untuk variabel pada Dummy, returns dan Acquisition CAR merupakan nilai pada tahun akuisisi. Selain itu, pengujian yang dilakukan oleh Patatoukas dan Thomas (2010) menemukan bahwa tidak semua pasar dapat menggunakan model Basu. Jenis pasar yang lambat dalam merespon good news dan bad news tidak cocok menggunakan model Basu karena hasilnya akan menjadi bias. Hal ini disebabkan karena ketika perusahaan melaporkan adanya lagged earnings sebelum informasi mengenai laba tersebut direspon oleh pasar, maka hal ini menyebabkan tidak sampainya informasi kepada pasar secara tepat waktu yang akhirnya berdampak pada kebingunan masyrakat apakah laba perusahaan merupakan good news ataubad news. 


\section{LAMPIRAN}

Tabel 1. Hasil Uji Statistik Deskriptif

\begin{tabular}{|c|c|c|c|c|c|c|c|c|c|c|}
\hline \multirow{2}{*}{ Variabel } & \multicolumn{5}{|c|}{ Regresi 1 - AcqCAR +/- 30 hari } & \multicolumn{5}{|c|}{ Regresi 2 - AcqCAR +/- 365 hari } \\
\hline & $\mathrm{N}$ & Minimum & Maximum & Mean & $\begin{array}{c}\text { Std. } \\
\text { Deviation }\end{array}$ & $\mathrm{N}$ & Minimum & Maximum & Mean & $\begin{array}{c}\text { Std. } \\
\text { Deviation }\end{array}$ \\
\hline $\mathrm{X}$ & & $(0.22)$ & 0.82 & 0.07 & 0.11 & & $(0.22)$ & 0.27 & 0.06 & 0.08 \\
\hline $\mathrm{R}$ & & $(1.00)$ & 3.75 & 0.43 & 1.01 & & $(1.00)$ & 3.75 & 0.40 & 0.97 \\
\hline DR & & $(1.00)$ & 0 & $(0.10)$ & 0.19 & & $(1.00)$ & 0 & $(0.11)$ & 0.20 \\
\hline CAR & & $(0.01)$ & 0.02 & 0.00 & 0.00 & & $(0.05)$ & 0.36 & 0.02 & 0.05 \\
\hline CARD & & $(0.01)$ & 0.02 & $(0.00)$ & 0.00 & & $(0.05)$ & 0.36 & 0.01 & 0.05 \\
\hline CARR & & $(0.02)$ & 0.03 & 0.00 & 0.01 & & $(0.30)$ & 0.30 & 0.02 & 0.07 \\
\hline CARDR & 88 & $(0.01)$ & 0.00 & 0.00 & 0.00 & 86 & $(0.30)$ & 0.02 & $(0.00)$ & 0.03 \\
\hline LEVERAGERD & & $(245.82)$ & 0 & $(2.85)$ & 26.20 & & $(245.82)$ & 0 & $(2.92)$ & 26.50 \\
\hline LOGASSETR & & $(13.72)$ & 42.56 & 5.22 & 12.10 & & $(13.72)$ & 42.56 & 4.88 & 11.64 \\
\hline LOGASSETRD & & $(13.72)$ & 0 & (1.34) & 2.54 & & $(13.72)$ & 0 & $(1.37)$ & 2.56 \\
\hline MBR & & (1.91) & 12.45 & 0.55 & 1.67 & & (1.91) & 12.45 & 0.56 & 1.69 \\
\hline MBRD & & $(1.91)$ & 0 & $(0.18)$ & 0.37 & & $(1.91)$ & 0 & $(0.19)$ & 0.37 \\
\hline
\end{tabular}

Tabel 2. Statistik Frekuens Dummy Return

\begin{tabular}{lcccccc}
\hline \multicolumn{7}{c}{ Tabel 2. Statistik Frekuens Dummy Return } \\
Variabel & +/- 30 hari & & \multicolumn{3}{c}{+ - 365 hari } \\
Dummy & Frequency & Percent & Valid Percent & Frequency & Percent & Valid Percent \\
\hline 0 & 54 & 61.363 & 61.363 & 52 & 60.465 & 60.465 \\
1 & 34 & 38.636 & 38.636 & 34 & 39.534 & 39.534 \\
Total & 88 & 100 & 100 & 86 & 100 & 100 \\
\hline
\end{tabular}


Tabel 3. Hasil Uji Korelasi CAR +/- 30 Hari

\begin{tabular}{|c|c|c|c|c|c|c|c|c|c|c|c|c|c|c|}
\hline & & $\mathrm{X}$ & $\mathrm{D}$ & $\mathrm{R}$ & DR & CAR & CARD & CARR & CARDR & LEVERAGERD & LOGASSETR & LOGASSETRD & MBR & MBRD \\
\hline \multirow{2}{*}{$\mathrm{X}$} & $\begin{array}{l}\text { Pearson } \\
\text { Correlation }\end{array}$ & 1 & -0.19 & $0.226^{*}$ & 0.103 & 0.14 & 0.117 & 0.07 & -0.208 & -0.194 & $0.236^{*}$ & 0.102 & -0.029 & 0.156 \\
\hline & $\begin{array}{l}\text { Sig. (2- } \\
\text { tailed) }\end{array}$ & & 0.076 & 0.034 & 0.338 & 0.195 & 0.277 & 0.514 & 0.052 & 0.071 & 0.027 & 0.343 & 0.791 & 0.146 \\
\hline \multirow{2}{*}{$\mathrm{D}$} & $\begin{array}{l}\text { Pearson } \\
\text { Correlation }\end{array}$ & -0.19 & 1 & $0.555^{* *}$ & $0.676^{* *}$ & -0.184 & -0.027 & -0.116 & 0.021 & -0.138 & $-0.572^{* *}$ & $-0.667^{* *}$ & $0.491^{* *}$ & $0.637^{* * *}$ \\
\hline & $\begin{array}{l}\text { Sig. (2- } \\
\text { tailed) }\end{array}$ & 0.076 & & 0 & 0 & 0.086 & 0.8 & 0.282 & 0.845 & 0.2 & 0 & 0 & 0 & 0 \\
\hline \multirow{2}{*}{$\mathrm{R}$} & $\begin{array}{l}\text { Pearson } \\
\text { Correlation }\end{array}$ & $0.226^{*}$ & $0.555^{* *}$ & 1 & $0.480^{* *}$ & 0.109 & 0.014 & 0.01 & 0 & 0.096 & $0.998^{* *}$ & $0.476^{* *}$ & $0.473^{* *}$ & $0.426^{* *}$ \\
\hline & $\begin{array}{l}\text { Sig. (2- } \\
\text { tailed) }\end{array}$ & 0.034 & 0 & & 0 & 0.311 & 0.896 & 0.929 & 0.995 & 0.372 & 0 & 0 & 0 & 0 \\
\hline \multirow{2}{*}{ DR } & $\begin{array}{l}\text { Pearson } \\
\text { Correlation }\end{array}$ & 0.103 & $0.676^{* *}$ & $0.480^{* *}$ & 1 & 0.121 & 0.013 & 0.087 & 0.042 & 0.196 & $0.501^{* *}$ & $0.999^{* *}$ & $0.414^{* *}$ & $0.807^{* *}$ \\
\hline & $\begin{array}{l}\text { Sig. (2- } \\
\text { tailed) }\end{array}$ & 0.338 & 0 & 0 & & 0.263 & 0.904 & 0.42 & 0.695 & 0.067 & 0 & 0 & 0 & 0 \\
\hline \multirow{2}{*}{ CAR } & $\begin{array}{l}\text { Pearson } \\
\text { Correlation }\end{array}$ & 0.14 & -0.184 & 0.109 & 0.121 & 1 & $0.682^{* *}$ & $0.511^{* *}$ & $-.524^{* *}$ & $-0.314^{* *}$ & 0.124 & 0.127 & 0.136 & 0.149 \\
\hline & $\begin{array}{l}\text { Sig. (2- } \\
\text { tailed) }\end{array}$ & 0.195 & 0.086 & 0.311 & 0.263 & & 0 & 0 & 0 & 0.003 & 0.249 & 0.239 & 0.208 & 0.167 \\
\hline \multirow{2}{*}{ CARD } & $\begin{array}{l}\text { Pearson } \\
\text { Correlation }\end{array}$ & 0.117 & -0.027 & 0.014 & 0.013 & $0.682^{* *}$ & 1 & -0.115 & $-0.768^{* *}$ & $-0.497^{* *}$ & 0.017 & 0.024 & 0.024 & 0.064 \\
\hline & $\begin{array}{l}\text { Sig. (2- } \\
\text { tailed) }\end{array}$ & 0.277 & 0.8 & 0.896 & 0.904 & 0 & & 0.288 & 0 & 0 & 0.876 & 0.825 & 0.827 & 0.556 \\
\hline \multirow{2}{*}{ CARR } & $\begin{array}{l}\text { Pearson } \\
\text { Correlation }\end{array}$ & 0.07 & -0.116 & 0.01 & 0.087 & $0.511^{* *}$ & -0.115 & 1 & 0.151 & 0.136 & 0.028 & 0.083 & 0.08 & 0.071 \\
\hline & $\begin{array}{l}\text { Sig. (2- } \\
\text { tailed) }\end{array}$ & 0.514 & 0.282 & 0.929 & 0.42 & 0 & 0.288 & & 0.161 & 0.205 & 0.793 & 0.442 & 0.461 & 0.512 \\
\hline \multirow{2}{*}{ CARDR } & $\begin{array}{l}\text { Pearson } \\
\text { Correlation }\end{array}$ & $0.208^{-}$ & 0.021 & 0 & 0.042 & $0.524^{* *}$ & $0.768^{* *}$ & 0.151 & 1 & $0.782^{* *}$ & -0.004 & 0.023 & -0.015 & -0.033 \\
\hline & $\begin{array}{l}\text { Sig. }(2- \\
\text { tailed })\end{array}$ & 0.052 & 0.845 & 0.995 & 0.695 & 0 & 0 & 0.161 & & 0 & 0.968 & 0.833 & 0.891 & 0.757 \\
\hline
\end{tabular}


Leona Ami\&Yie Ke Feliana,Hubungan Antara Tingkat Konservatisme Pihak Pengakuisisi Dan TingkatReturnKegiatan Merger-Akuisisi Dari

PerspektifPihakPengakuisisi

\begin{tabular}{|c|c|c|c|c|c|c|c|c|c|c|c|c|c|c|}
\hline \multirow{2}{*}{ LEVERAGERD } & $\begin{array}{l}\text { Pearson } \\
\text { Correlation }\end{array}$ & $0.194^{-}$ & -0.138 & 0.096 & 0.196 & $0.314^{--}$ & $0.497^{--}$ & 0.136 & $0.782^{* *}$ & 1 & 0.097 & 0.181 & 0.07 & 0.098 \\
\hline & $\begin{array}{l}\text { Sig. (2- } \\
\text { tailed) }\end{array}$ & 0.071 & 0.2 & 0.372 & 0.067 & 0.003 & 0 & 0.205 & 0 & & 0.366 & 0.092 & 0.517 & 0.361 \\
\hline \multirow{2}{*}{ LOGASSETR } & $\begin{array}{l}\text { Pearson } \\
\text { Correlation }\end{array}$ & $0.236^{*}$ & $0.572^{--}$ & $0.998^{* *}$ & $0.501^{* *}$ & 0.124 & 0.017 & 0.028 & -0.004 & 0.097 & 1 & $0.498^{* *}$ & $0.479^{* *}$ & $0.445^{* *}$ \\
\hline & $\begin{array}{l}\text { Sig. (2- } \\
\text { tailed) }\end{array}$ & 0.027 & 0 & 0 & 0 & 0.249 & 0.876 & 0.793 & 0.968 & 0.366 & & 0 & 0 & 0 \\
\hline \multirow{2}{*}{ LOGASSETRD } & $\begin{array}{l}\text { Pearson } \\
\text { Correlation }\end{array}$ & 0.102 & $0.667^{--}$ & $0.476^{* *}$ & $0.999^{* *}$ & 0.127 & 0.024 & 0.083 & 0.023 & 0.181 & $0.498^{* *}$ & 1 & $0.412^{* *}$ & $0.811^{* *}$ \\
\hline & $\begin{array}{l}\text { Sig. (2- } \\
\text { tailed) }\end{array}$ & 0.343 & 0 & 0 & 0 & 0.239 & 0.825 & 0.442 & 0.833 & 0.092 & 0 & & 0 & 0 \\
\hline \multirow{2}{*}{ MBR } & $\begin{array}{l}\text { Pearson } \\
\text { Correlation }\end{array}$ & $0.029^{-}$ & $0.491^{\text {** }}$ & $0.473^{* *}$ & $0.414^{* *}$ & 0.136 & 0.024 & 0.08 & -0.015 & 0.07 & $0.479^{* *}$ & $0.412^{* *}$ & 1 & $0.443^{* *}$ \\
\hline & $\begin{array}{l}\text { Sig. (2- } \\
\text { tailed) }\end{array}$ & 0.791 & 0 & 0 & 0 & 0.208 & 0.827 & 0.461 & 0.891 & 0.517 & 0 & 0 & & 0 \\
\hline \multirow{2}{*}{ MBRD } & $\begin{array}{l}\text { Pearson } \\
\text { Correlation }\end{array}$ & 0.156 & $0.637^{--}$ & $0.426^{* *}$ & $0.807^{* *}$ & 0.149 & 0.064 & 0.071 & -0.033 & 0.098 & $0.445^{* *}$ & $0.811^{* *}$ & $0.443^{* *}$ & 1 \\
\hline & $\begin{array}{l}\text { Sig. (2- } \\
\text { tailed) }\end{array}$ & 0.146 & 0 & 0 & 0 & 0.167 & 0.556 & 0.512 & 0.757 & 0.361 & 0 & 0 & 0 & \\
\hline
\end{tabular}


Tabel 4. Hasil Uji Korelasi CAR +/- 365 Hari

\begin{tabular}{|c|c|c|c|c|c|c|c|c|c|c|c|c|c|c|}
\hline & & & & & & & & & & & LOGASS & LOGAS & & \\
\hline & & $X$ & $\mathrm{D}$ & $\mathrm{R}$ & DR & CAR & CARD & CARR & CARDR & LEVERAGERD & ETR & SETRD & MBR & MBRD \\
\hline \multirow[t]{2}{*}{$\mathrm{X}$} & $\begin{array}{l}\text { Pearson } \\
\text { Correlation }\end{array}$ & \multirow[t]{2}{*}{1} & -0.194 & 0.000 & 0.093 & -0.070 & -0.117 & -0.027 & 0.054 & $-0.297^{* *}$ & 0.014 & 0.093 & -0.035 & 0.175 \\
\hline & Sig. (2-tailed) & & 0.073 & 0.994 & 0.392 & 0.520 & 0.282 & 0.807 & 0.621 & 0.005 & 0.896 & 0.396 & 0.752 & 0.107 \\
\hline \multirow[t]{2}{*}{$\mathrm{D}$} & $\begin{array}{l}\text { Pearson } \\
\text { Correlation }\end{array}$ & -0.194 & 1 & $-0.564^{* *}$ & $-0.673^{* *}$ & -0.082 & 0.154 & $-0.316^{* *}$ & -0.121 & -0.137 & $-0.582^{* *}$ & $-0.664^{* *}$ & $-0.498^{* *}$ & $-0.634^{* *}$ \\
\hline & Sig. (2-tailed) & 0.073 & & 0.000 & 0.000 & 0.455 & 0.158 & 0.003 & 0.265 & 0.209 & 0.000 & 0.000 & 0.000 & 0.000 \\
\hline \multirow[t]{2}{*}{$\mathrm{R}$} & $\begin{array}{l}\text { Pearson } \\
\text { Correlation }\end{array}$ & 0.000 & $-0.564^{* *}$ & 1 & $0.491^{* *}$ & $0.236^{*}$ & -0.123 & $0.837^{* *}$ & 0.130 & 0.098 & $0.998^{* *}$ & $0.487^{* *}$ & $0.500^{* *}$ & $0.435^{* *}$ \\
\hline & Sig. (2-tailed) & 0.994 & 0.000 & & 0.000 & 0.028 & 0.260 & 0.000 & 0.232 & 0.369 & 0.000 & 0.000 & 0.000 & 0.000 \\
\hline \multirow[t]{2}{*}{ DR } & $\begin{array}{l}\text { Pearson } \\
\text { Correlation }\end{array}$ & 0.093 & $-0.673^{* *}$ & $0.491^{* *}$ & 1 & -0.109 & $-0.281^{* *}$ & $0.352^{* *}$ & $0.385^{* *}$ & 0.195 & $0.513^{* *}$ & $0.999^{* *}$ & $0.419^{* *}$ & $0.806^{* *}$ \\
\hline & Sig. (2-tailed) & 0.392 & 0.000 & 0.000 & & 0.317 & 0.009 & 0.001 & 0.000 & 0.072 & 0.000 & 0.000 & 0.000 & 0.000 \\
\hline \multirow[t]{2}{*}{ CAR } & $\begin{array}{l}\text { Pearson } \\
\text { Correlation }\end{array}$ & -0.070 & -0.082 & $0.236^{*}$ & -0.109 & 1 & $0.889^{* *}$ & -0.077 & $-0.761^{* *}$ & 0.017 & $0.235^{*}$ & -0.096 & 0.138 & 0.114 \\
\hline & Sig. (2-tailed) & 0.520 & 0.455 & 0.028 & 0.317 & & 0.000 & 0.480 & 0.000 & 0.877 & 0.030 & 0.381 & 0.205 & 0.294 \\
\hline \multirow[t]{2}{*}{ CARD } & $\begin{array}{l}\text { Pearson } \\
\text { Correlation }\end{array}$ & -0.117 & 0.154 & -0.123 & $-0.281^{* *}$ & $0.889^{* *}$ & 1 & $-0.433^{* *}$ & $-0.853^{* *}$ & -0.015 & -0.125 & $-0.264^{*}$ & -0.062 & -0.030 \\
\hline & Sig. (2-tailed) & 0.282 & 0.158 & 0.260 & 0.009 & 0.000 & & 0.000 & 0.000 & 0.892 & 0.251 & 0.014 & 0.573 & 0.787 \\
\hline CARR & $\begin{array}{l}\text { Pearson } \\
\text { Correlation }\end{array}$ & -0.027 & $-0.316^{* *}$ & $0.837^{* *}$ & $0.352^{* *}$ & -0.077 & $-0.433^{* *}$ & 1 & $0.492^{* *}$ & 0.039 & $0.826^{* *}$ & $0.342^{* *}$ & $0.303^{* *}$ & 0.195 \\
\hline
\end{tabular}


Leona Ami\&Yie Ke Feliana,Hubungan Antara Tingkat Konservatisme Pihak Pengakuisisi Dan TingkatReturnKegiatan Merger-Akuisisi Dari PerspektifPihakPengakuisisi

\begin{tabular}{|c|c|c|c|c|c|c|c|c|c|c|c|c|c|c|}
\hline & Sig. (2-tailed) & 0.807 & 0.003 & 0.000 & 0.001 & 0.480 & 0.000 & & 0.000 & 0.718 & 0.000 & 0.001 & 0.005 & 0.072 \\
\hline \multirow[t]{2}{*}{ CARDR } & $\begin{array}{l}\text { Pearson } \\
\text { Correlation }\end{array}$ & 0.054 & -0.121 & 0.130 & $0.385^{* *}$ & $-0.761^{* *}$ & $-0.853^{* *}$ & $0.492^{* *}$ & 1 & 0.008 & 0.134 & $0.367^{* *}$ & 0.058 & 0.065 \\
\hline & Sig. (2-tailed) & 0.621 & 0.265 & 0.232 & 0.000 & 0.000 & 0.000 & 0.000 & & 0.938 & 0.220 & 0.001 & 0.596 & 0.550 \\
\hline \multirow[t]{2}{*}{$\begin{array}{l}\text { LEVERA } \\
\text { GERD }\end{array}$} & $\begin{array}{l}\text { Pearson } \\
\text { Correlation }\end{array}$ & $-0.297^{* *}$ & -0.137 & 0.098 & 0.195 & 0.017 & -0.015 & 0.039 & 0.008 & 1 & 0.099 & 0.180 & 0.071 & 0.098 \\
\hline & Sig. (2-tailed) & 0.005 & 0.209 & 0.369 & 0.072 & 0.877 & 0.892 & 0.718 & 0.938 & & 0.363 & 0.097 & 0.519 & 0.372 \\
\hline \multirow[t]{2}{*}{$\begin{array}{l}\text { LOGASS } \\
\text { ETR }\end{array}$} & $\begin{array}{l}\text { Pearson } \\
\text { Correlation }\end{array}$ & 0.014 & $-0.582^{* *}$ & $0.998^{* *}$ & $0.513^{* *}$ & $0.235^{*}$ & -0.125 & $0.826^{* *}$ & 0.134 & 0.099 & 1 & $0.509^{* *}$ & $0.505^{* *}$ & $0.455^{* *}$ \\
\hline & Sig. (2-tailed) & 0.896 & 0.000 & 0.000 & 0.000 & 0.030 & 0.251 & 0.000 & 0.220 & 0.363 & & 0.000 & 0.000 & 0.000 \\
\hline \multirow[t]{2}{*}{$\begin{array}{l}\text { LOGASS } \\
\text { ETRD }\end{array}$} & $\begin{array}{l}\text { Pearson } \\
\text { Correlation }\end{array}$ & 0.093 & $-0.664^{* *}$ & $0.487^{* *}$ & $0.999^{* *}$ & -0.096 & $-0.264^{*}$ & $0.342^{* *}$ & $0.367^{* *}$ & 0.180 & $0.509^{* *}$ & 1 & $0.416^{* *}$ & $0.810^{* *}$ \\
\hline & Sig. (2-tailed) & 0.396 & 0.000 & 0.000 & 0.000 & 0.381 & 0.014 & 0.001 & 0.001 & 0.097 & 0.000 & & 0.000 & 0.000 \\
\hline \multirow[t]{2}{*}{ MBR } & $\begin{array}{l}\text { Pearson } \\
\text { Correlation }\end{array}$ & -0.035 & $-0.498^{* *}$ & $0.500^{* *}$ & $0.419^{* *}$ & 0.138 & -0.062 & $0.303^{* *}$ & 0.058 & 0.071 & $0.505^{* *}$ & $0.416^{* *}$ & 1 & $0.447^{* *}$ \\
\hline & Sig. (2-tailed) & 0.752 & 0.000 & 0.000 & 0.000 & 0.205 & 0.573 & 0.005 & 0.596 & 0.519 & 0.000 & 0.000 & & 0.000 \\
\hline \multirow[t]{2}{*}{ MBRD } & $\begin{array}{l}\text { Pearson } \\
\text { Correlation }\end{array}$ & 0.175 & $-0.634^{* *}$ & $0.435^{* *}$ & $0.806^{* *}$ & 0.114 & -0.030 & 0.195 & 0.065 & 0.098 & $0.455^{* *}$ & $0.810^{* *}$ & $0.447^{* *}$ & 1 \\
\hline & Sig. (2-tailed) & 0.107 & 0.000 & 0.000 & 0.000 & 0.294 & 0.787 & 0.072 & 0.550 & 0.372 & 0.000 & 0.000 & 0.000 & \\
\hline
\end{tabular}


Tabel 5. Hasil Uji Regresi

\begin{tabular}{lrrrrrr}
\hline & \multicolumn{3}{c}{ AcqCAR +/- 30 hari } & \multicolumn{3}{c}{ AcqCAR +/- 365 hari } \\
& $\mathrm{B}$ & $\mathrm{t}$ & \multicolumn{1}{c}{ Sig. } & \multicolumn{1}{c}{$\mathrm{B}$} & \multicolumn{1}{c}{$\mathrm{t}$} & \multicolumn{1}{c}{ Sig. } \\
\hline (Constant) & 0.07 & 3.256 & 0.002 & 0.072 & 4.177 & 0 \\
D & -0.018 & -0.482 & 0.631 & -0.023 & -0.84 & 0.404 \\
R & -0.304 & -1.355 & 0.179 & -0.212 & -1.328 & 0.188 \\
DR & 1.346 & 1.032 & 0.305 & 0.772 & 0.824 & 0.413 \\
CAR & -3.579 & -0.611 & 0.543 & 0.667 & 1.109 & 0.271 \\
CARD & 0.185 & 0.022 & 0.982 & -1.042 & -1.526 & 0.131 \\
CARR & 2.643 & 0.772 & 0.442 & -0.239 & -0.544 & 0.588 \\
CARDR & -28.158 & -0.935 & 0.353 & -0.107 & -0.154 & 0.878 \\
LEVERAGERD & 0 & -0.697 & 0.488 & 0 & -3.033 & 0.003 \\
LOGASSETR & 0.028 & 1.49 & 0.14 & 0.018 & 1.399 & 0.166 \\
LOGASSETRD & -0.112 & -1.119 & 0.267 & -0.065 & -0.932 & 0.355 \\
MBR & -0.016 & -1.886 & 0.063 & -0.009 & -1.482 & 0.143 \\
MBRD & 0.06 & 1.083 & 0.282 & 0.056 & 1.402 & 0.165 \\
F-test (sig.) & & & 0.115 & & & 0.027 \\
Adj. R Square & & & 0.074 & & & 0.135 \\
\hline
\end{tabular}

Tabel 6. Hasil Uji CAR +/- 30 Hari

\begin{tabular}{lcr}
\multicolumn{2}{c}{ Variabel } & \multicolumn{2}{c}{ AcqCAR +/- 30 Hari } \\
& T & \multicolumn{1}{c}{ Sig. } \\
\hline $\mathrm{D}$ & -0.92941 & 0.355342 \\
$\mathrm{R}$ & 1.444069 & 0.152439 \\
$\mathrm{DR}$ & -0.56687 & 0.572312 \\
F-test & & 0.152 \\
(Sig.) & & 0.61 \\
R Square & & \\
\hline
\end{tabular}


Tabel 7. Hasil Uji CAR +/- 365 Hari

\begin{tabular}{lrr}
\hline \multirow{2}{*}{ Variabel } & AcqCAR $+/-365$ Hari \\
& T & \multicolumn{1}{c}{ Sig. } \\
\hline D & -1.97015 & 0.052196 \\
R & -1.17966 & 0.241547 \\
DR & -0.24679 & 0.805691 \\
F-test & & 0.189 \\
(Sig.) & & 0.056 \\
$R$ Square & & \\
\hline
\end{tabular}

Tabel 8. Hasil Uji Beda Rata - Rata untuk AcqCAR +/- 30 Hari

\begin{tabular}{ccc}
\hline Keterangan & & $\begin{array}{c}\text { Uji t } \\
\text { Sig. (2-tailed) }\end{array}$ \\
\hline \multirow{2}{*}{$-30 \&+30$} & Equalas variances assumed & 0.168 \\
& Equal Variances not & 0.169 \\
assumed & 0.503 \\
-30 s.d 0 \& 0 s/d & $\begin{array}{c}\text { Equalas variances assumed } \\
\text { Equal Variances not }\end{array}$ & 0.503 \\
\hline
\end{tabular}

Tabel 9. Hasil Uji Beda Rata - Rata untuk AcqCAR +/- 365 Hari

\begin{tabular}{ccc}
\hline Keterangan & & Sig. (2-tailed) \\
\hline$-365 \&+365$ & $\begin{array}{c}\text { Equalas variances } \\
\text { assumed }\end{array}$ & 0.488 \\
& $\begin{array}{c}\text { Equal Variances not } \\
\text { assumed } \\
\text { Equalas variances } \\
\text { assumed }\end{array}$ & 0.489 \\
-365 s.d $0 \& 0 \mathrm{~s} / \mathrm{d}+365$ & $\begin{array}{c}\text { Equal Variances not } \\
\text { assumed }\end{array}$ & 0.199 \\
& 0.199 \\
\hline
\end{tabular}




\section{DAFTAR PUSTAKA}

Anataranews.2015.Tren Merger Perusahaan di Indonesia Belum akan Berubah.

Ball,R.,2001.Infrastructure requirements for an economically efficient system of public financial reporting and disclosure.Brookings-Wharton Paperson Financial Services, $127-182$.

Ball, R., Shivakumar, L., 2005. Earnings quality in UK private firms. Journal of Accounting and Economics 39, 83-128.

Bushman, R., Chen, Q., Engel, E., Smith, A., 2004. Financial accounting information, organizational complexity and corporate governance systems. Journal of Accounting and Economics 37, 167-201.

Demsetz, H., Lehn, K., 1985. The structure of corporate ownership: causes and consequences. Journal of Political Economy 93, 1155-1177.

Easton, Peter D et al.2008. Price-convexity, debt - related agency costs, and timely loss recognition.

Francis, Jere R., Martin, Xiumin. 2010. Acquisition Profitability and Timely Loss Recognition. Journal of Accounting and Economics 49, 161-178

Hayn, C. 1995. The Information Content of Losses. Journal of Accounting and Economics 20: $125-153$.

Indonesia Stock Exchage. 2010

Komisi Pengawas Persaingan Usaha.2015.Gelombang Merger Melanda : Bangga atau Waspada?

Lin, Hsiou-wei and Maureen F. McNichols.Underwriting Relationships, Analysts' Earnings Forecasts and Investment Recommendations.Journal of Accounting and Economics.

Masulis, R., Wang, C., Xie, F., 2007.Corporate governance and acquirer returns. Journal of Finance 62, 1851-1889.

Moradi, Mehdi et al. 2010. A study of The Effect of Financial Leverage on Earnings Respone Coefficient through out Income Aprroach : Iranian Approach. International Review of Accounting, Business, and Finance, Vol.2 ,No.2, 103-115.

Niresh, J. Aloy and Velnampy,T. 2014. Firm Size and Profitability : a study of Listed Manufacturing Firms in Sri Lanka. International Journal of Business and Management, Vol. 9,No. 4.

Patatoukas, Panos N. 2010. More Evidence of Bias in Basu (1997) Estimates of Conditional Conservatism.

Roberts, Alexander et al. 2003. Mergers and Acquisitions.Heriot-Watt University. 
Schwert, G. William. 1996. Markup Pricing in Mergers and Acquistions. Journal of Finance Economics 41,pg. 153-192.

Skinner, Douglas J. 1994. Why Firm Voluntarily Disclosure Bad News. Journal of Accounting Research 32, 38-60

Sugiarto, Agus. 2000. The Effect of Mergers and Acquisitions of Shareholder Returns.Victoria University of Technology.

Wang,zhe. 2009. Accounting Conservatism.Victoria University of Wellington

Watts, R., 2003. Conservatism in accounting. Part I: explanations and implications. Accounting Horizons 17, 207-221.

Weygandt, Jerry $\mathrm{J}$ et al.accounting principles. 2013. 